\title{
Behavioral Rehearsal untuk Mengatasi Kecemasan Belajar Daring (Online) Masa Pandemi Covid-19
}

\author{
Handayani Sura', Muhammad Junaedi Mahyuddin, M Yasdar, Nur Aina, Nurul Aifah, \\ Muh Hafiz Ashari \\ Prodi Bimbingan dan Konseling, Universitas Muhammadiyah Enrekang
}

\begin{abstract}
Abstrak
Tujuan penelitian ini adalah untuk mengetahui cara mengatasi kecemasan belajar daring dengan pendekatan behavioral rehearsal dan upaya yang dilakukan untuk mengatasi kecemasan belajar daring (online) pada masa pandemi covid-19 pada siswa SMA di Kecamatan Alla Kabupaten Enrekang. Metode penelitian dalam penelitian ini adalah metode penelitian kualitatif, dimana penelitian ini menghasilkan data berupa kata tertulis atau lisan dari orang-orang dan perilaku yang diamati.Hasil pembahasan adalah Behavioral Rehearsal dapat mengatasi kecemasan belajar daring pada masa pandemi covid-19 dengan cara latihan melalui cara: mempraktekkan perilaku yang dicontohkan, memberikan motivasi kepada siswa tentang strategi-strategi (penguatan) dan langkah dalam mengerjakan tugas dan juga belajar daring.

Kata Kunci :Covid-19, Behavioral Rehearsal, Kecemasan Belajar Daring
\end{abstract}

\begin{abstract}
The purpose of this study was to find out how to deal with online learning anxiety with the behavioral rehearsal approach and the efforts made to overcome online learning anxiety during the Covid-19 pandemic in high school students in Alla District, Enrekang Regency. The research method in this study is a qualitative research method, where this research produces data in the form of written or spoken words from people and observed behavior. The result of the discussion is that Behavioral Rehearsals can overcome online learning anxiety during the Covid-19 pandemic by training through : practicing exemplary behavior, motivating students about strategies (reinforcement) and steps in doing assignments and also learning online.

Keywords: Covid-19, Behavioral Rehearsal, Online Learning Anxiety
\end{abstract}




\section{PENDAHULUAN}

Pendidikan merupakan salah satu sektor penting dalam pembangunan negara. Menurut UndangUndang Nomor 20 Tahun 2003 tentang Sistem Pendidikan Nasional, menerangkan bahwa pendidikan merupakan usaha sadar dan terencana untuk mewujudkan suasana belajar dan proses pembelajaran agar siswa secara aktif mengembangkan potensi dirinya untuk memiliki kekuatan spiritual, pengendalian diri, kepribadian, kecemasan, akhlak mulia, serta keterampilan yang diperlukan dirinya, masyarakat, bangsa, dan negara.

Upaya yang dapat dilakukan untuk peningkatan kualitas pendidikan adalah mengembangkan pembelajaran yang berorientasi pada siswa. Pembelajaran yang berorientasi pada siswa dapat dilakukan dengan membangun sistem pembelajaran yang memungkinkan siswa memiliki kemampuan untuk belajar lebih menarik, interaktif, dan bervariasi. Siswa harus mampu memiliki kompetensi yang berguna bagi masa depannya. Seiring dengan perkembangan teknologi berikut infrastruktur penunjangnya, upaya peningkatan kualitas pembelajaran dapat dilakukan melalui pemanfaatan teknologi tersebut dalam suatu sistem yang dikenal dengan belajar daring (online). Apalagi pada masa sekarang yaitu masa pandemi covid-19, jalan terbaik untuk melakukan pembelajaran dengan siswa ataupun mahasiswa adalah dengan mengupayakan pembelajaran berbasis daring (Online). Pembelajaran ini sangat berbeda dengan pembelajaran konvensional yang terjadi di sekolah maupun di perguruan tinggi. Guru dan Dosen tidak berhadapan langsung dengan murid ataupun mahasiswa mereka melainkan secara jarak jauh yang memungkinkan siswa ataupun mahasiswa berada pada tempat yang berbeda.

Belajar daring (online) adalah pembelajaran melalui internet atau jaringan yang memungkinkan atau didukung oleh penggunaan alat digital dan melibatkan beberapa bentuk interaktivitas berupa interaksi online antara siswa dan guru atau kelompok mereka. Secara proses belajar daring (online) diatur dalam Permendikbud Nomor 22 Tahun 2016 tentang standar proses dengan prinsip sebagai berikut: 1) Dari siswa diberi tahu menjadi siswa mencari tahu, 2) Dari guru sebagai satu-satunya sumber belajar menjadi belajar berbasis aneka sumber belajar, 3) Dari pendekatan tekstual menuju proses sebagai penguatan penggunaan pendekatan ilmiah, 4) Dari pembelajaran berbasis konten menuju pembelajaran berbasis kompetensi, 5) Dari pembelajaran parsial menuju pembelajaran terpadu, 6) Dari pembelajaran yang menekankan jawaban tunggal menuju pembelajaran dengan jawaban yang kebenarannya multi dimensi, 7) Dari pembelajaran verbalisme menuju keterampilan aplikatif, 8) Peningkatan dan keseimbangan antara keterampilan fisikal (hardskill) dan keterampilan mental (softskills), 9) Pembelajaran yang mengutamakan pembudayaan dan pemberdayaan siswa sebagai pembelajar sepanjang hayat, 10) Pemanfaatan teknologi informasi dan komunikasi untuk meningkatkan efisiensi dan efektivitas pembelajaran.

Belajar daring (online) menurut Hamalik (2013) merupakan suatu sistem yang dapat memfasilitasi siswa belajar lebih luas, lebih banyak, dan bervariasi. Melalui fasilitas yang disediakan oleh sistem tersebut, siswa dapat belajar kapan dan dimana saja tanpa terbatas oleh jarak, ruang dan waktu. Materi pembelajaran yang dipelajari lebih bervariasi, tidak hanya dalam bentuk verbal, melainkan lebih bervariasi seperti visual, audio, dan gerak. 
Melihat pentingnya belajar daring (online) sebagai alat untuk mengukur keberhasilan siswa maupun mahasiswa dalam menempuh pendidikan, hal tersebut menjadi tantangan dan beban tersendiri bagi mereka. Belajar daring (online) menjadi sesuatu yang menakutkan bagi mereka, sehingga ada kecemasan yang muncul ketika perkuliahan atau pembelajaran daring (online) itu dilakukan, bagaimana tidak semua harus menggunakan internet, seperti tugas, diskusi dan lainlain.

Kecemasan belajar daring (online) pada masa pandemic covid-19, walaupun dianggap suatu yang wajar dan tidak seluruhnya merugikan bahkan dalam tingkat dibutuhkan terutama yang berkaitan dengan motivasi belajar. Akan tetapi pada kenyataannya, kecemasan belajar daring (online) dapat berakibat buruk terhadap hasil belajar dan prestasi belajar. Bahkan apabila kecemasan tersebut terlalu berlebihan akan mempengaruhi kehidupan akademik dan sosial siswa juga mahasiswa dan berakibat rendahnya motivasi mereka.

Kecemasan belajar daring (online) sendiri merupakan salah satu masalah psikologis yang sering dialami oleh siapapun termasuk siswa dan juga mahasiswa. Kecemasan menurut Andang dan Ujam (2013) merupakan suatu respon dari pengalaman yang dirasa tidak menyenangkan dan diikuti perasaan gelisah, khawatir, dan takut. Kecemasan merupakan aspek subjektif dari emosi seseorang karena melibatkan faktor perasaan yang tidak menyenangkan yang sifatnya subjektif dan timbul karena menghadapi tegangan, ancaman kegagalan, perasaan tidak aman, konflik dan biasanya individu tidak menyadari dengan jelas apa yang menyebabkan ia mengalami kecemasan (Shalih, 2006).

Kecemasan menurut Makmun (2010) didefinisikan sebagai kekhawatiran yang kurang jelas atau tidak berdasar, merasa gelisah (takut dan khawatir). kecemasan merupakan suatu ketegangan yang memuncak sehingga menimbulkan kegelisahan dan kehilangan kendali akibat adanya penilaian yang subjektif dari proses komunikasi interpersonal. Selanjutnya Yusuf (2011) menyatakan bahwa kecemasan adalah suatu keadaan aperhensih atau keadaan khawatir yang mengeluhkan bahwa sesuatu yang buruk akan segera terjadi.

Sigmund Freud dalam Yustinus (2013) mengatakan bahwa kecemasan adalah keadaan afektif yang dirasa tidak menyenangkan yang diikuti oleh gejala fisik yang memperingatkan seseorang akan bahaya yang dirasa mengancam perasaan tidak menyenangkan ini biasanya tidak jelas, sulit dipastikan, tetapi selalu terasa.Kemudian Ujam (2015) menjelaskan bahwa kecemasan (anxiety) yaitu perasaan yang sifatnya umum, dimana seseorang merasa ketakutan atau kehilangankepercayaan diri yang tidak jelas asal maupun wujudnya.

Siswa yang mengalami kecemasan dalam belajar daring (online) pada masa pandemi covid-19 ini, umumnya merasa khawatir terhadap kemungkinan-kemungkinan terburuk yang akan dialaminya, seperti tidak bisa mengerjakan tugas, karena jaringan yang kadang tidak mendukung, belum lagi ketika mereka tidak memiliki computer atau laptop dan akses internet, yang digunakan untuk bisa kuliah atau belajar daring (online), dan juga ada kecemasan nantinya akan mendapatkan nilai yang jelek. Selain itu ketika mereka di rumah terus mereka akan bosan dengan kagiatan mereka yang hanya belajar sendiri tanpa bertatap muka langsung dengan teman mereka. Gejala-gejala sindromatik belajar daring (online) pada masa ini tentu perlu dicermati dan diatasi secara tepat, baik dari mahasiswa sendri, orang tua maupun dari guru.

Kecemasan tersebut perlu penanganan yang tepat melalui perubahan prilaku. Perubahan perilaku bertujuan untuk mengubah perilaku manusia yang bisa diamati dan dapat diukur. Perubahan-perubahan itu dipilih sesuai kebutuhan masalah yang dihadapi, dengan tujuan untuk melihat perubahan perilaku. Salah satu teknik sebagai terapi perilaku adalah behavioral rehearsal.

Behavioral rehearsal merupakan salah satu di antara banyak teknik yang berasal dari terapi perilaku menurut Thorpe \& Olson (Brandle T. Elford, 2016). Teknik sebagai terapi perilaku awalnya disebut behavioristic psychodrama (psikodrama behavioristik), adalah campuran terapi 
conditioned reflex (refleks terkondisi) dari salter, teknik psikodrama dari moreno dan fixed role therapy (terapi peran tetap) dari kelly (Elford, 2016). Namun yang lebih sering digunakan adalah behavior rehearsal (latihan/geladi perilaku) dengan klien yang perlu menjadi sadar sepenuhnya akan dirinya.

Teknik behavioral rehearsal adalah suatu bentuk bermain-peran di mana klien mempelajari suatu tipe perilaku baru di luar situasi konseling. Behavioral rehearsal memasukkan beberapa komponen kunci : menirukan perilaku, menerima umpan balik dari konselor, dan sering mempraktikkan/ melatih perilaku yang diinginkan.

Naugle dan Maher (2008) menyarankan bahwa konselor dan klien seharusnya mengupayakan dan menguasai keterampilan-keterampilan sederhana terlebih dahulu, baru kemudian pindah ke keterampilan-keterampilan yang lebih kompleks. Naugle dan Maher memberikan langkah-langkah berikut untuk digunakan konselor dalam mengimplementasikan teknik behavioral rehearsal, sebagai berikut : 1. Praktikkan perilaku yang dicontohkan, 2. Bangun motivasi klien melalui strategi-strategi reinforcement (penguatan) positif, 3. Beri klien banyak umpan balik konkret terfokus untuk membantu klien menguasai keterampilan dimaksud, 4. Berbicara sebagai orang pertama, dengan menggunakan kata sayasecara regular, 5. Menyetujui pujian konselor, dan 6. Berimprovisasi, hidup untuk saat ini.

Tujuan penelitian ini adalah Untuk mengetahui cara mengatasi kecemasan belajar daring dengan pendekatan behavioral rehearsal dan upaya yang dilakukan untuk mengatasi kecemasan belajar daring (online) masa pandemi covid-19 pada Pada Siswa SMA Di Kecamatan Alla Kabupaten Enrekang.

\section{METODE}

Metode yang digunakan dalam penelitian ini adalah metode penelitian kualitatif, dimana penelitian ini menghasilkan data berupa kata tertulis atau lisan dari orang-orang dan perilaku yang diamati (Sugiyono, 2016). Disini penulis bermaksud menggambarkan dan menjelaskan bagaimana Behavioral Rehearsal untuk mengatasi kecemasan belajar daring (online) masa pandemi covid-19 pada Pada Siswa Sma Di Kecamatan Alla Kabupaten Enrekang.

\section{PEMBAHASAN}

Memberikan behavior rehearsal dalam bentuk latihan. Teknik behavior rehearsal diterapkan dalam bentuk bermain peran dimana klien mempelajari suatu tipe perilaku baru di luar situasi konseling. behavior rehearsal memasukkan beberapa komponen kunci yaitu: menirukan perilaku, menerima umpan balik dari konselor, dan sering mempraktekkan/melatih perilaku yang diinginkan (Elford, 2016). Upaya yang dilakukan bersama dalam satu kelompok, dengan tujuan untuk memberikan pengalaman belajar bersama dalam penangan masalah kecemasan tersebut. Demikian dijelaskan Walsh menemukan teknik behavior rehearsal berguna ketika menangani orang-orang yang mengalami kecemasan.

Pendekatan behavior rehearsal untuk mengatasi kecemasan belajar daring (online) masa pandemi covid-19 pada Pada Siswa Sma Di Kecamatan Alla Kabupaten Enrekang.

Hasil wawancara dengan guru bimbingan dan konseling sebagai berikut:

"Kecemasan jelas dirasa oleh setiap siswa, namanya juga anak-anak, dia selalu merasa takut dan khawatir. Kami para guru selalu memberi motivasi kepada siswa, kami selalu memberi nasehat kepada siswa kami, bahwasanya kalau kita belajar itu tidak perlu khawatir. Karena dengan kita belajar, Insyaallah kita pasti bisa menyelesaikan tugas nantinya.

Dari hasil wawancara dengan salah satu guru bimbingan dan konseling memberikan kami selaku peneliti untuk lebih termotivasi membantu para siswa yang membutuhkan bantuan. Salah 
satu yang dilakukan adalah memberikan latihan bermain peran. Agar siswa tidak lagi mengalami kecemasan.

Penerapan behavioral rehearsal ini dalam bentuk konseling kelompok.

"Strategi yang digunakan dalam pendekatan behavioral rehearsal yaitu dengan cara memberikan konseling kepada siswa dalam pembelajaran daring (online) kelompok"

Hal senada juga di ungkapkan oleh salah satu siswa yaitu sebagai berikut:

"Strategi yang digunakan peneliti dalam pendekatan behavioral rehearsal untuk mengatasi kecemasankami para siswa yang dilakukan adalah dengan cara memanggil setiap siswa yang merasakan kecemasan belajar daring (online) dan peneliti memberikan latihan dan juga nasehat dan motivasi kepada kami para siswa.

Konseling sebagai sebuah profesi yang sifatnya membantu (heping profession), sebagai sebuah helping professional, konseling dilakukan dengan berbagai prosedur, salah satunya melalui prosedur kelompok (Kurnanto, 2013). Konseling kelompok dapat memberikan individu berbagai pengalaman kelompok yang membantu mereka belajar secara efektif, mengembangkan toleransi terhadap stres dan kecemasan, dan menemukan kepuasan dalam bekerja dan hidup bersama orang lain (Corey, 2012).

Perubahan perilaku para siswa setelah mendapatkan pelatihan menurut salah satu guru bimbingan konseling mengatakan bahwa:

"Alhamdulillah dengan adanya kegiatan pelatihan tersebut beserta solusi-solusinya yang diberikan kepada siswa, telah berjalan dengan efektif hal itu terbukti dengan menurunnya jumlah siswa yang mengalami kecemasan belajar daring (online)" (Wawancara Juni 2020).

Adapun jawaban salah satu kepala sekolah yaitu:

"Alhamdulillah dengan dilaksanakannya pendekatan behavioral rehearsel untuk mengatasi kecemasan belajar daring (online) pada msa pandemi ini, pendekatan ini mampu mengatasi kecemasan yang dirasakan oleh siswa. Hal ini jelas terlihat dari siswa yang mengalami kecemasan belajar daring (online) semakin berkurang"

Upaya yang dilakukan teknik behavior rehearsal dengan bentuk konseling kelompok akan memberikan pengalaman belajar yang dapat merubah perilaku-perilaku siswa sebagai subjek sasaran dalam penelitian ini.

\section{SIMPULAN}

Upaya yang dilakukan teknik behiavior rehearsal dengan bentuk konseling kelompok akan memberikan pengalaman belajar yang dapat merubah perilaku-perilaku siswa sebagai subjek sasaran dalam penelitian ini..

\section{DAFTAR PUSTAKA}

Andang, H\& Ujam, J. 2013. Psikologi Kepribadian (Lanjutan). Bandung: Pustaka Setia.

Corey, G. (2012). The Theory and practise of group counseling. 8rd ed. Pacific Grove, California: Books/Cole

Elford, Brandle T. (2016). 40 teknik yang harus diketahui setiap konselor (edisi kedua) Pustaka Pelajar. Yogyakarta

Hamalik, O. 2013. Proses Belajar Mengajar. Jakarta: Bumi Aksara.

Kurnanto,M.Edi. (2013). Konseling Kelompok.Bandung; Alfabeta

Makmun, K. 2014. Psikologi Belajar. Yogyakarta: Aswaja Pressindo. . 2014. Psikologi Konseling. Yogyakarta: Aswaja Pressindo. 
Naugle dan Maher (2008). Modeling and Behavioral rehearsal. Dalam W.O'Donohue,J.E. Fisher, \& S.C.

Shalih, M. M. 2006. Terapi Mengatasi Kecemasan. Jakarta: Rohani Press

Sugiyono. 2016. Metode Penelitian Pendidikan Pendekatan Kuantitatif, Kualitatif, R\&D. Alfabeta, Bandung.

Syamsu, Yusuf \& Juntika, A. Nurihsan. 2011. Teori Kepribadian. Bandung: Remaja Rosdakarya.

Ujam, J. 2015. Dinamika Kepribadian (Psikodinamik). Bandung: Pustaka Setia.

Permendikbud Nomor 22 Tahun 2016 Tentang Standar Proses.

Yustinus, S. 2006. Teori Kepribadian dan Terapi Psikoanalitik Freud. Yogyakarta: Kanisius.

Yusuf, S. 2011. Psikologi Anak dan Remaja. Bandung: Remaja Rosdakarya Offset 